\title{
Do public work schemes deter or encourage outmigration? Empirical evidence from China
}

\author{
Nancy H Chau, Ravi Kanbur and Yu Qin
}

\author{
* Correspondence: \\ yq38@cornell.edu \\ Charles H. Dyson School of Applied \\ Economics and Management, \\ Cornell University, Ithaca, NY 14850, \\ USA
}

\begin{abstract}
How does the introduction of rural public work schemes impact individual incentives to migrate? This paper examines this question in the context of rural public work program (Yigong-daizhen) in China, and unveils empirical evidence that suggest that the introduction of Yigong-daizhen projects in fact stimulates outmigration at the village level, after controlling for village characteristics, project types and province fixed effects. By furthermore accounting for the endogeneity of Yigong-daizhen placement using propensity score matching method, the impact of such projects is found to be consistent with the OLS estimation. These results are consistent with household migration behavior in the presence of significant cost of migration, and credit market imperfection.

JEL codes: H43; J61; $\mathrm{O} 15$

Keywords: Public work scheme; Migration; China
\end{abstract}

\section{Introduction}

A distinctive feature of the Chinese economic growth experience has been the massive increase in rural migrant work force living in China's cities since the onset of economic reforms in the 1980's. By 2007, the estimated number of rural migrants exceeded over 135 million (Meng et al. 2010). The mobilization of this sizeable workforce has wideranging consequences, including contributions to the growth of export industries (Chan 2008), shifts in income distribution between urban and rural China (Ha et al. 2009), and changes in educational and health outcomes over time between migrants and non-migrants (Lee 2011), for example. The depth and breadth of these research studies concerning the consequences of rural-urban migration in China contrast sharply with the relatively limited number of studies on the effectiveness of migration policies in China. Indeed, much of the policy discourse on China's internal migration policy has focused on the hukou system of household registration (Chan 2008). As a first objective of this paper, we examine the role of rural public work schemes as an alternative migration regulatory mechanism in the Chinese context.

To the best of our knowledge, this is a first attempt at an empirical assessment of the role of Yigong-daizhen programs on the pattern of migration in China. As a contribution to policy analysis, in view of the massive influx of rural migrants into China's urban cities, whether these rural public work schemes serve as deterrents that mitigate the size of the migrant flow, or in fact further intensify out migration is a question of 
critical policy importance. As a contribution to the economics of migration, this paper brings together three strands of the literature not often discussed together: labor market consequence of public work schemes, determinants of regional migration, and behavior in the presence of credit market imperfection.

By a public work scheme, we refer to the public provision of employment opportunities resulting in the creation of public goods, such as roads and schools. These employment opportunities serve as a form of social safety net, at a prescribed wage for those unable to find alternative employment. Worldwide, the implementation of public work schemes spans transition countries, developing countries and developed countries (Betcherman et al. 2004). A number such public work schemes, such as the Maharashtra Employment Guarantee Scheme (EGS), and more recently the Mahatma Gandhi Employment Guarantee Schemes in India, have attracted much academic and policy attention, (Acharya 1990; Ravallion et al. 1993; Gaiha 1996a, b, 2000; Basu et al. 2009). Research on the labor market consequences of these more well-known public work schemes has so far focused on employment, earnings, and targeting. ${ }^{1,2,3}$

By contrast, the labor market consequence of public work schemes in China is a far less well-understood topic. Specifically, Yigong-daizhen - to offer job opportunities instead of sheer relief - is a public work scheme initiated in the mid-1980s a part of the Chinese government's poverty reduction programs (Rozelle and Park 1998). Research on the effectiveness of these programs has been very limited. Two exceptions are Park et al. (2002) and Zhu and Jiang (1995), emphasizing respectively the targeting effectiveness, and the earnings impact of Yigong-daizhen programs. ${ }^{4,5}$ While offering valuable insights, neither of these studies identify program-specific effects due mainly to data limitation. In addition, identification also requires proper accounting of endogeneity of program selection among participating villages or county - these are issues that we will pay particular attention to in our analysis in the sequel.

This paper is also related to a rapidly growing literature on the determinants of interregional migration in China. Some of these determinants include the potential role of farmland shortages and availability of household labor (Zhao 1999a), earning differences between destinations and origins (Zhao 1999b; Zhu 2002; Zhang and Song 2003), as well as the cost of migration (Zhang and Song 2003) whether monetary or psychic (Sjaastad 1962). At the household level, participating in migration has been shown to significantly raise per capita income as high as 16 to 43 percent (Taylor et al. 2003). Open questions abound. In particular, what roles do policies play in regulating the direction and size of the flow of internal migrants in China? Indeed, how do the direct provision of employment opportunities and the provision of public goods in rural villages impact the outflow of migrants from rural areas? ${ }^{6}$

Finally, this paper is also related to the literature on behavior in the presence of credit market imperfection. In a wide variety of settings, credit market imperfections have been shown to fundamentally alter the properties of equilibrium, giving rise for example to non-monotonic, and/or distributionally sensitive comparative statics responses (Galor and Zeira 1993; Matsuyama 2008). In the context of migration, credit market imperfection is expected to play a critical role particularly when the upfront cost of migration is significant. Indeed, several studies (Du et al. 2005; McKenzie and Rapoport 2007) document an inverted-U shape relationship between household endowments and migration likelihood. That is, households with middle wealth are more willing to and able to migrate. Some 
recent empirical evidences from Indonesia (Bazzi 2013) and Mexico (Angelucci 2013) suggest that relaxing financial constraints encourage international migration, particularly in households in which financial constraints to migration are binding at the margin.

Following the lessons that can be drawn from these three strands of literature, we argue that Yigong-daizhen programs introduce two opposing forces on the village level propensity for outmigration. By increasing available employment opportunities and raising earnings and production efficiency through public goods provision in general, Yigong-daizhen programs narrows the expected earnings gap between destination and sending locations, thus potentially discouraging outmigration. Going in the opposite direction, by raising individual/household's ability to pay for the cost of migration, due either to the improvements in earnings thanks to Yigong-daizhen programs in the face of credit market imperfection that has previously deterred attempts to migrate, or to public construction that directly decreases the cost of migration by improving transportation and building roads, public work schemes can in fact stimulate outmigration. On balance, the net outcome of Yigong-daizhen programs on village level outmigration will in the end depend on the relative strength of these two effects. ${ }^{7}$

In this paper, we take this issue to the data using the Center for Chinese Agricultural Policy (CCAP) 2003 Village Survey, covering 2,459 villages in six provinces in China (Jiangsu, Sichuan, Shaanxi, Gansu, Hebei and Jilin in the year of 2003. We are interested in assessing the outmigration impact of introducing Yigong-daizhen programs at the village level. In order to identify program-specific effects, we employ a difference in difference approach. To furthermore account for the issue of endogenous program selection, we employ a difference in difference propensity score matching method. In a series of regressions, the preponderance of the evidence suggests that Yigong-daizhen programs have in fact facilitated the outmigration of workers. Consistent with Du et al. (2005) and McKenzie and Rapoport (2007) and the implications of models with significant cost of migration and imperfect credit markets, we also find an inverted U-shape relationship between average per capita income and outmigration at the village level. Finally, to address the potential heterogeneity of Yigong-daizhen programs across villages, we compare the impact of Yigong-daizhen in (A) villages with and without productivity improving public projects, such as irrigation system improvement, drainage system improvement, soil improvement, small-scale water conservation and terrace construction projects, (B) villages with and without migration cost decreasing public investments through roads and bridge construction projects, and $(\mathrm{C})$ villages with and without higher program intensity (in terms of number of projects, labor and capital use). The impacts of Yigong-daizhen programs on outmigration in these specifications continue to be positive and significant, and especially pronounced in villages with newly constructed roads, suggesting the potentially critical roles that cost of migration and credit market imperfections play in the determination of the inter-regional flow of migrants in China. We also find that the impacts of Yigong-daizhen are larger in villages with more than one Yigong-daizhen projects, and with above average labor participation.

The plan of the rest of this paper is as follows. Section 2 describes the institutional background of Yigong-daizhen program in China. Section 3 provides the summary of statistics of the data used in this paper. Section 4 discusses about the identification strategy. Section 5 shows the empirical findings and Section 6 concludes. 


\section{Background}

The Yigong-daizhen program in China was initiated in the mid-1980s by the Chinese government as part of the nation's rural poverty-reduction programs. Table 1 shows the types of projects, the amount of investment and the achievements of Yigong-daizhen projects from 1985 to 2000 . In terms of program goals, there are mainly four general categories, including rural land construction and irrigation system construction, road construction, drinking water facilities improvements and small-scale water conservation. Forestry and meadow maintenance, river and lake conservation are also included in the Yigong-daizhen project schemes from 1985 to 1995.

The amount of investment on each category of Yigong-daizhen projects is also presented in Table 1. Rural land construction, irrigation system construction, as well as road construction take up around 60 per cent of the total investment in 1985-1995, and around 80 per cent of the total investment in 1995-2000. Total investment in Yigong-daizhen projects is substantial, amounting to 2.62 billion yuan, or around US\$ 0.38 billion.

The Chinese central government provided both monetary and in-kind investments. Table 2 shows the types of in-kind investment made by the government, such as cereals, cloth, edible oil, grains and medium- and low-grade consumer goods. In the year 2005, the Regulation of Yigong-daizhen Projects was implemented (National Development and Reform Commission NDRC 2005). The legislation laid out the regulations that governed the implementation of Yigong-daizhen projects. Before the end of each calendar year, the Development and Reform Commission at the provincial level are to report to the National Development and Reform Commission about project plans for Yigong-daizhen in the following year. Furthermore, the National Development and Reform Commission are expected to prepare a national level Yigong-daizhen projects plan according to the various

Table 1 Basic background of Yigong-daizhen projects in China

\begin{tabular}{|c|c|c|c|}
\hline Projects & Period & $\begin{array}{l}\text { Investment } \\
\text { (billion yuan) }\end{array}$ & Achievement \\
\hline $\begin{array}{l}\text { Rural land construction and } \\
\text { irrigation system construction }\end{array}$ & 1985-1995 & 7.3 & $\begin{array}{l}\text { Developed new terraces: } 21 \text { million mu; } \\
\text { improve low fertility land: } 14 \text { million mu; } \\
\text { improve irrigation: } 51 \text { million mu. }\end{array}$ \\
\hline Road construction & 1985-1995 & 10.05 & Improve rural roads: 214.4 thousands kilometers \\
\hline Drinking water supply facilities & 1985-1995 & 3.5 & $\begin{array}{l}\text { Provide drinking water supply for } 40.9 \\
\text { million people and } 33 \text { million livestocks }\end{array}$ \\
\hline $\begin{array}{l}\text { Forestry and meadow maintenance, } \\
\text { small-scale water conservation }\end{array}$ & 1985-1995 & 2.7 & $\begin{array}{l}\text { Tree Planting: } 22.7 \text { million mu; New and } \\
\text { improved meadow: } 10 \text { million mu; } \\
\text { Small-scale water conservation: } \\
28 \text { thousands square kilometers }\end{array}$ \\
\hline River and Lake Conservation & 1991-1995 & 8 & $\begin{array}{l}2 \text { billion yuan has been invested annually } \\
\text { since the flood in } 1991 \text { to improve the water } \\
\text { condition of several important river and lakes }\end{array}$ \\
\hline $\begin{array}{l}\text { Rural land construction and } \\
\text { irrigation system construction }\end{array}$ & 1995-2000 & 10 & $\begin{array}{l}\text { Rural land construction: } 30 \text { million mu; } \\
\text { improve irrigation: } 40 \text { million mu. }\end{array}$ \\
\hline Drinking water supply facilities & 1995-2000 & 3.5 & $\begin{array}{l}\text { Provide drinking water supply for about } \\
40 \text { million people and } 30 \text { million livestocks }\end{array}$ \\
\hline Road construction & 1995-2000 & 9 & $\begin{array}{l}\text { Improve rural roads: around } 100 \\
\text { thousands kilometers }\end{array}$ \\
\hline Small-scale water conservation & 1995-2000 & 1.5 & $\begin{array}{l}\text { Small-scale water conservation: around } \\
30 \text { thousands square kilometers }\end{array}$ \\
\hline
\end{tabular}

Source: Documents issued by the National Development and Reform Commission referring to Yigong-daizhen projects, 1985-1995; 1995-2000. 
Table 2 Chinese Government investment in Yigong-daizhen Projects, 1984-93

\begin{tabular}{llll}
\hline Scheme number & Planned period & In-kind goods invested & Converted value of the goods \\
\hline 1 & $1984-87$ & Cereals, cotton and cloth & 2.7 \\
2 & $1989-91$ & $\begin{array}{l}\text { Medium- and low-grade } \\
\text { consumer goods }\end{array}$ & 0.6 \\
3 & $1990-92$ & Industrial goods & 1.5 \\
4 & $1991-95$ & Foodgrains & 5 \\
5 & $1991-95$ & Foodgrains and industrial goods & 10 \\
6 & $1993-97$ & $\begin{array}{l}\text { Cereals, cloth, edible oil, medium- } \\
\text { and low-grade consumer goods }\end{array}$ & 10 \\
\hline
\end{tabular}

Source: Zhu and Jiang (1995) Table 4.1.

economic condition of each province. In terms of payments to contracted laborers, the Regulation of Yigong-daizhen projects stipulates that wages should be paid without delay and default. In some provinces, such as Sichuan, information on each Yigong-daizhen project, including source of funding, expected outcomes, as well as implementation year of the projects are published online and made open for public scrutiny.

The main difference between the Yigong-daizhen programs in China and other public work schemes, such as the EGS program in India, is the wage rate paid to the employed workers and the potential impact that this has on inter-regional migration. It is documented that the wage paid to the unskilled day laborers in the local villages was around 10 yuan (around 1.5 USD) per day during the year 1998 to 2002. This was much lower than the wage of migrant workers (Luo et al. 2007). For example, in the rural area of Sichuan province in 1995, an out-migrant helped to increase an average of 2,388 yuan more of household earnings than a non-migrants per year, relative to an average net income per capita of 1354.66 yuan and an average household size around 4, or around 10 yuan per day assuming that a worker works five days a week (Zhao 1999a). Thus, a ruralurban wage gap continued to exist, and remained large despite the introduction of Yigongdaizhen programs. By contrast, the EGS in Neelamangalam, India, for example, pays the minimum wage at 80 rupees a days, a figure very close to the day wages of unskilled migrants, which could be less than 100 rupees a day (Naomi 2008).

\section{Data description}

The village level data used in this paper is obtained from Center for Chinese Agricultural Policy (CCAP) 2003 Village Survey. It surveyed 2,459 villages in six provinces in China, namely Jiangsu, Sichuan, Shaanxi, Gansu, Hebei and Jilin in the year of 2003. The survey collected a great deal of information about village affairs. In addition to the basic village characteristics, the survey collected information on village level public goods investment, governance systems, as well as the general regulatory environment, such as 1) the attitude of upper government toward violation of One Child Policy, 2) whether women married into the village are eligible for land allocation and 3) how long it generally takes to get a license for small business, for example.

As a subset of public investment projects dedicated to alleviating rural poverty in China, Yigong-daizhen is a public work scheme initiated in 1984. ${ }^{9}$ The funding of the Yigong-daizhen projects is allocated to the local governments for local infrastructure construction using local laborers, where the payment to the laborers accounts for around 20 per cent of the total funding, at a wage around 10 yuan (around 1.5 USD) per person per day (Luo et al. 2007). 
Table 3 displays program related summary statistics exclusively related to Yigong-daizhen projects. There are in total 549 Yigong-daizhen projects between 1998 and 2002 in our sample. Among the 549 projects, 148 (26.96\%) projects are roads and bridges construction. Electricity and drinking water facilities are the second and third popular projects in terms of the type of the Yigong-daizhen projects. The average investment of a Yigong-daizhen project is 17,249.05 yuan, and this represents around 11 percent of the average investment of all the public investment projects. The average labor used of a Yigong-daizhen project is 1,534.51 day laborers per project, which is almost doubled compared to the average labor used of all the public projects. On average a Yigong-daizhen project benefits 342.9 households, higher than the average coverage of all the public investment projects.

In addition to the variation in the types of project, the availability of Yigong-daizhen project also varies across villages in our surveyed sample. Among all the 2,430 villages with valid information, 2,109 villages do not have access to Yigong-daizhen project; 200 villages have only one Yigong-daizhen project; 121 villages have more than one such projects, with a maximum of six projects. On average, 13.2 percent of the surveyed villages receive at least one Yigongdaizhen project, with variations in different provinces, ranging from 0.8 to 21.8 percent.

It is worth noting that Yigong-daizhen is the only kind of public work scheme in China which hires local laborers for local public construction with compensation through hourly wages. Other types of public projects in Chinese villages do not hire local wage laborers, thus not belonging to public work programs which hire local unemployed people. Instead, the other projects contract with construction companies outside of the villages. In the empirical estimation, the type of other public projects available in the villages will be

Table 3 Summary of statistics of Yigong-daizhen projects $(N=549)$

\begin{tabular}{|c|c|c|c|c|}
\hline Project & Number of projects & $\begin{array}{l}\text { Average } \\
\text { investment (yuan) }\end{array}$ & $\begin{array}{l}\text { Average } \\
\text { labor used }\end{array}$ & $\begin{array}{l}\text { Benefit } \\
\text { household }\end{array}$ \\
\hline Roads and bridges & 148 & 18511.72 & 2406.39 & 530 \\
\hline School construction & 41 & 13125.61 & 412.33 & - \\
\hline Build clinic & 7 & 2114.29 & 124.29 & - \\
\hline Drinking water & 56 & 12552 & 1007.27 & 246.13 \\
\hline Irrigation system & 61 & 18196.33 & 893.53 & 298.58 \\
\hline Drainage system & 15 & 9240 & 580 & 465.73 \\
\hline Electricity & 70 & 36714.75 & 1320.78 & 494.35 \\
\hline Telephone & 24 & 35027.27 & 1820.52 & 282.45 \\
\hline Cable TV or loudspeaker & 5 & 3320 & 130 & 784.6 \\
\hline Soil improvement & 16 & 16713.33 & 3942 & 394.88 \\
\hline Small-scale water conservation & 19 & 8894.74 & 2342.22 & 337.16 \\
\hline Terrace construction & 23 & 8773.81 & 1785.7 & 135.32 \\
\hline Environment improvement & 15 & 6800 & 461.47 & 185.6 \\
\hline Forest closure & 9 & 1200 & 631.11 & 215.5 \\
\hline Public forest & 8 & 6325 & 1141.67 & 423.43 \\
\hline Grain for Green ${ }^{8}$ & 24 & 7378.75 & 1755.96 & 249.17 \\
\hline Meadow construction & 0 & 0 & 0 & 0 \\
\hline Recreational center & 4 & 5700 & 107.5 & 725.5 \\
\hline Not indicated & 4 & 7250 & 533.33 & 935.33 \\
\hline All sample & 549 & 17249.05 & 1534.51 & 342.9 \\
\hline
\end{tabular}


controlled for in order to correct for the potential impact of different types of other ongoing projects on migration. However, as non- Yigong-daizhen public projects do not generate cash income for the local laborers, their impact on migration is likely to be trivial.

The key outcome variable in this paper is the number of migrants in a village. The CCAP 2003 Village Survey collects very detailed information about village demographics and other characteristics in 1997 and 2002. In the questionnaire, there is a question asking "How many villagers worked outside, and lived outside in 1997 and 2002." We use this information as a measurement of the number of migrants in a village.

It is worth noting that the village information in 1997 is recalled from the village head, thus subject to potential recall bias. However, this should not affect the credibility of our results for two main reasons. First, village officials in China usually maintain very detailed records about village demographics. For example, it is not a surprise that the village head knows very well the employment history of each member in the village. Therefore, the data about village characteristics in 1997 should be trustworthy. Second, even if the migration data is subject to recall bias, it will not bias our estimation results as long as it is not correlated with the placement of Yigong-daizhen projects.

\section{Econometric issues and identification strategies}

\subsection{Endogenous program selection}

Naturally, whether Yigong-daizhen projects are implemented in a village is likely to depend on village characteristics to begin with. Based on information available from our sample, Yigong-daizhen projects are more likely to be implemented in villages with more surplus laborers and less income per capita if it is correctly targeted. Table 4 shows the initial differences in village characteristics by Yigong-daizhen status. Results from t-tests between the two groups show that villages with Yigong-daizhen projects on average have significantly lower net income per capita, larger village size (higher total population), more migrants in terms of both absolute value and share of population,

Table 4 Descriptive statistics by Yigong-daizhen status

\begin{tabular}{|c|c|c|c|c|c|c|}
\hline \multirow{2}{*}{$\frac{\text { Village Variables in } 1997}{\text { Income per capita }}$} & \multicolumn{2}{|c|}{ All } & \multicolumn{2}{|c|}{ Yigong-daizhen = 1} & \multicolumn{2}{|c|}{ Yigong-daizhen $=0$} \\
\hline & 1457.83 & $(973.91)$ & $1367.91^{*}$ & $(848.71)$ & 1471.72 & $(991.29)$ \\
\hline Total population & 1439.40 & $(1072.93)$ & $1664.12^{* * *}$ & $(1178.29)$ & 1404.69 & $(1051.75)$ \\
\hline Number of migrants & 91.86 & $(133.77)$ & $140.23^{* * *}$ & $(203.20)$ & 84.49 & $(118.06)$ \\
\hline Share of migrants & 0.06 & $(0.06)$ & $0.07^{* * *}$ & $(0.08)$ & 0.06 & $(0.06)$ \\
\hline Irrigated land (mu) & 1107.36 & $(1724.88)$ & 1184.27 & $(1754.51)$ & 1095.48 & $(1720.38)$ \\
\hline Proportion of land steeper than 25 degrees (\%) & 24.52 & $(29.30)$ & $27.25^{*}$ & $(31.84)$ & 24.10 & $(28.87)$ \\
\hline $\begin{array}{l}\text { The distance from the village committee } \\
\text { seat to the nearest tarred road }\end{array}$ & 6.75 & $(23.63)$ & $8.89^{*}$ & $(55.85)$ & 6.42 & (12.86) \\
\hline $\begin{array}{l}\text { Distance from village committee seat } \\
\text { to township seat }\end{array}$ & 5.38 & $(5.30)$ & 5.83 & (6.08) & 5.31 & $(5.17)$ \\
\hline Number of fellow villagers working at township & 2.32 & $(4.46)$ & $2.76^{* *}$ & $(4.50)$ & 2.25 & $(4.45)$ \\
\hline Illiterate person in 1997 & 59.52 & $(110.94)$ & 63.27 & $(87.32)$ & 58.94 & $(114.16)$ \\
\hline $\begin{array}{l}\text { Any tarred road passing through your village? } \\
1=\text { yes; } 2=\text { no }\end{array}$ & 1.68 & $(0.47)$ & 1.71 & $(0.45)$ & 1.67 & $(0.47)$ \\
\hline Observations & 2430 & & 325 & & 2105 & \\
\hline
\end{tabular}

Notes. ${ }^{* * *}$ denotes significant at the 0.01 level; ${ }^{* *}$ denotes significant at the 0.05 level; *denotes significant at the 0.1 level. Standard deviation is reported in the parentheses. 
higher proportion of land steeper than 25 degrees, longer distance from the village committee (usually locating near the center of the village) to the nearest tarred road and more fellow villagers working at township. These suggest strongly that the endogeneity of program placement needs to be accounted for in our econometric model.

\subsection{Unobserved heterogeneity}

Due to data limitation, we do not have information on the implementation of Yigongdaizhen projects in the surveyed villages prior to year 1997. Thus, it is likely that labor market equilibrium in the villages was affected not only by the Yigong-daizhen projects implemented during year 1998-2002, but also by the ones implemented before 1997. To mitigate the impact of these unobservable differences across villages, we employ a difference in difference approach using the balanced panel data. Assuming that the long term impacts of such projects do not vary significantly across years, the resulting estimates should provide an unbiased assessment of the impact of Yigong-daizhen projects.

In view of these econometric issues and identification challenges, we will provide first a series of baseline OLS regressions of a difference in difference model, which is specified as follows:

$$
\begin{aligned}
\text { Outmig }_{\mathrm{i}, \mathrm{t}}= & \alpha+\beta_{1} \text { YGDZ }_{\mathrm{i}}+\beta_{2} \text { After }_{\mathrm{t}}+\beta_{3} \text { YGDZ }_{\mathrm{i}} * \text { After }_{\mathrm{t}}+\beta_{4} \text { Village }_{\mathrm{i}, \mathrm{t}} \\
& +\sum \gamma_{\mathrm{k}} \text { Project }, \mathrm{k}_{\mathrm{i}, \mathrm{t}}+\sum \Phi_{\mathrm{j}} \text { Province }, \mathrm{j}+\varepsilon_{\mathrm{i}, \mathrm{t}}
\end{aligned}
$$

where Outmig $g_{i, t}$ is the number of out-migrants in village $i$, time $t^{10}$ YGDZ is a binary variable that indicates whether Yigong-daizhen projects had been implemented in village $\mathrm{i}^{11}$ Village $_{i, t}$ controls for socio-economic, demographic, governance, and transportation related village level characteristics in year $t$ that we take as proxy for various push factors of migration. These include net income per capita (yuan in natural log), squared income per capita (yuan in natural log), the number of illiterates, total population, the distance from village committee seat to township government seat, the number of fellow villagers working at the upper government (township government,) and whether there are tarred roads passing through the village. ${ }^{12}$ As there were 19 types of public investment projects in the surveyed villages, Project, $\mathrm{k}_{\mathrm{i}, \mathrm{t}}$ controls for other types of prevailing public investment projects in the villages via fixed effects, that is, Project, $k_{i, t}$ if a type $k$ project had been implemented in village $\mathrm{i}$, time $\mathrm{t}$, otherwise Project, $\mathrm{k}_{\mathrm{i}, \mathrm{t}}=0$. There were 19 types of other public investment projects as reported in the questionnaires, which did not hire local labor. Province, $j$ controls for provincial fixed effects. $\varepsilon_{\mathrm{i}, \mathrm{t}}$ is an error term. ${ }^{13}$

In order to deal with the endogeneity of the non-random placement of Yigongdaizhen projects, we will additionally provide estimates based on Differencein-Difference Propensity Score Matching and compare the results with the Differencein-Difference analysis to test the robustness of our results. Propensity Score Matching compares the outcomes of treated and untreated individuals by linking individuals with similar characteristics. Average Treatment Effects (ATE) - which is the causal difference between the villages with and without Yigong-daizhen program conditional on village characteristics can be calculated by PSM estimator.

As we have data before and after the Yigong-daizhen program, we use a Differencein-Difference Propensity Score Matching (DID-PSM) procedure as our estimation strategy, which is superior to conventional PSM in terms of removing bias from the 
treatment effect estimates (Heckman et al. 1998). The average treatment effect given by DID-PSM estimator is

$$
\begin{aligned}
\Delta_{\text {DID PSM }} & =\mathrm{E}\left[\left(\mathrm{Y}_{\mathrm{t}}^{2}-\mathrm{Y}_{\mathrm{c}}^{2}\right)-\left(\mathrm{Y}_{\mathrm{t}}^{1}-\mathrm{Y}_{\mathrm{c}}^{1}\right) \mid \mathrm{X}\right] \\
& =\mathrm{E}\left[\left(\mathrm{Y}_{\mathrm{t}}^{2}-\mathrm{Y}_{\mathrm{t}}^{1}\right) \mid \mathrm{X}\right]-\mathrm{E}\left[\left(\mathrm{Y}_{\mathrm{c}}^{2}-\mathrm{Y}_{\mathrm{c}}^{1}\right) \mid \mathrm{X}\right]
\end{aligned}
$$

where $Y_{t}^{1}$ is the outcome for the treatment group before the treatment; $Y_{t}^{2}$ is the outcome for the treated group after the treatment; $\mathrm{Y}_{\mathrm{c}}^{1}$ is the outcome for the treatment group before the treatment; $\mathrm{Y}_{\mathrm{c}}^{2}$ is the outcome for the treatment group after the treatment; $\mathrm{X}$ is the set of control variables. Therefore, the DID-PSM estimator measures the expected difference between the treatment and control groups, before and after the Yigong-daizhen program, accounting for observable characteristics.

In the first step of the DID-PSM analysis, we use a probit model to estimate the probability of Yigong-daizhen program placement on 46 covariates of village characteristics in the year of $1997 .{ }^{14}$ We then use the predicted probability from the probit model as the propensity score of Yigong-daizhen program. That is, a higher propensity score means a higher probability for a village to implement a Yigong-daizhen program. Figure 1 shows the common support of the propensity scores with and without Yigongdaizhen program. The box plot shows that there is a large common support in the two groups, which is necessary to carry out propensity score matching.

In the second step, we need to find out comparable villages both in the treated and non-treated groups. To do so, we divide the whole sample into deciles based on the propensity score. In each decile, we regress all the 46 covariates on the village Yigongdaizhen status. If the coefficient on Yigong-daizhen is not significant, it means that the selection of Yigong-daizhen program is random conditional on the specific covariate. The sample is balanced if that is the case.

Table 5 shows the balanced condition in the ten deciles. It can be seen from the table that only less than ten percent of the covariates have not been balanced in decile three, four, five, seven, eight, nine and ten, which is satisfactory. Decile one and two also have less than $20 \%$ of unbalanced covariates. Only decile six has $32.61 \%$ of unbalanced

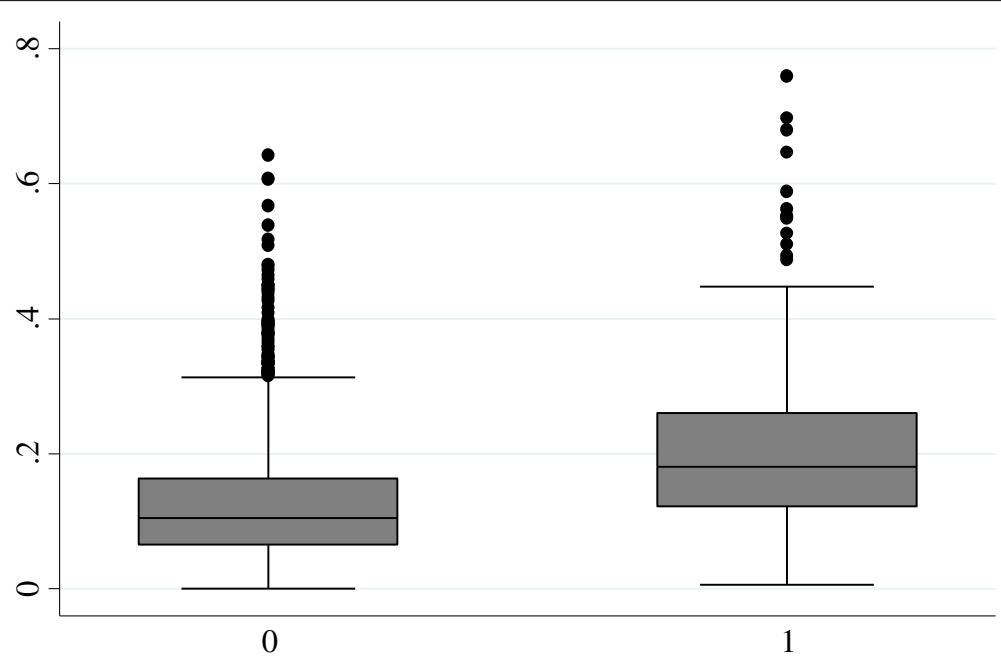

Figure 1 Common support of propensity score by Yigong-daizhen status. 
Table 5 Check for balanced condition

\begin{tabular}{llll}
\hline Quantile & Number of covariates & Unbalanced covariates & Percentage of unbalance \\
\hline 1 & 46 & 6 & 13.04 \\
2 & 46 & 8 & 17.39 \\
3 & 46 & 2 & 4.35 \\
4 & 46 & 2 & 4.35 \\
5 & 46 & 4 & 8.70 \\
6 & 46 & 15 & 32.61 \\
7 & 46 & 0 & 0.00 \\
8 & 46 & 4 & 8.70 \\
9 & 46 & 4 & 8.70 \\
10 & 46 & 1 & 2.17 \\
\hline
\end{tabular}

covariates. Since the overall balanced condition is good, we will use the propensity score under this model specification to carry out the DID-PSM estimator.

\subsection{Heterogeneity by income quartiles}

Our empirical estimation tests the impact of Yigong-daizhen on village level outmigration. As argued earlier in the introduction (Qin 2011), the impact of Yigong-daizhen on outmigration behavior will depend critically on (i) the cost of migration, and (ii) the presence of credit market imperfection. With significant upfront cost of migration and imperfect credit markets, we would expect Yigong-daizhen projects to have a positive impact on the number of outmigrants in the village. By contrast, if there is perfect credit market in the village that no households are bound by credit constraints, then improving employment prospects and earnings via Yigong-daizhen projects should have the opposing effect of decreasing the number of out-migrants. Importantly, the relative importance of the cost of migration and of imperfect credit markets is likely dependent on the average income of the village in question. To capture the potential heterogeneity in program impact by average per capita income in a village, we will provide quartile specific estimates of the impact of Yigong-daizhen projects on out-migration.

\subsection{Heterogeneity by program characteristics}

As discussed earlier in Section 1, different public investment projects should be expected to have different implications on the urban-rural wage gap, and the cost of migration in the Yigong-daizhen villages. In particular, productivity improving projects such as irrigation system improvement, drainage system improvement, soil improvement, small-scale water conservation and terrace construction projects may be viewed productivity improving, potentially narrowing the urban-rural wage gap. Other programs such as road and bridge construction may be seen more as migration cost reducing. To account for program-specific heterogeneity across Yigong-daizhen projects, we will do two groups of comparisons. In the first group, we compare the impact of Yigong-daizhen projects on migration between villages with five types of 'productivity improvement' projects and villages that lack 'productivity improvement' projects. In the second group, we compare the impact of Yigong-daizhen projects between villages with road and bridge construction projects, and as such, are more likely to experience migration cost reduction, and villages without road and bridge construction projects during the survey periods. 
Another dimension to examine the heterogeneity of program's impact is through the intensity of different Yigong-daizhen projects. It is likely that the impact of such projects should be larger in villages with more numbers of such projects, or more local labor participation. Therefore, we will compare the impact of Yigong-daizhen projects in villages with only one such project to the villages with more than one projects. Also, we will compare the impact in villages with below average labor participation for the Yigong-daizhen projects to the villages with above average labor participation in these projects.

\section{Empirical findings}

Table 6 presents the empirical results for the impact of Yigong-daizhen projects on the migration patterns in the villages. Columns 1-4 display the results of OLS estimation of the difference in difference (DID) setup. Column 1 is the parsimonious specification without any control variables, Column 2 controls for village characteristics, Column 3 further controls for project type fixed effect and Column 4 controls for both project type and

Table 6 Impact of Yigong-daizhen project on migrant labor

\begin{tabular}{|c|c|c|c|c|c|}
\hline & \multicolumn{5}{|c|}{ Dependent variable: change of migrant labor (person) } \\
\hline & DID (1) & DID (2) & DID (3) & DID (4) & DID-PSM \\
\hline \multirow[t]{2}{*}{ After } & $46.19^{* * *}$ & $41.79 * * *$ & $32.68^{* * *}$ & $46.44^{* * *}$ & - \\
\hline & $(1.88)$ & $(2.14)$ & $(8.45)$ & $(7.80)$ & \\
\hline \multirow[t]{2}{*}{ Yigong-daizhen } & $55.71^{* * *}$ & $38.16^{* * *}$ & $38.68^{* * *}$ & 5.85 & - \\
\hline & $(11.62)$ & $(9.59)$ & $(9.62)$ & $(9.17)$ & \\
\hline \multirow[t]{2}{*}{ After*Yigong-daizhen } & $40.44^{* * *}$ & $40.30^{* * *}$ & $36.07^{* * *}$ & $38.04^{* * *}$ & $12.16^{*}$ \\
\hline & $(7.96)$ & $(7.88)$ & $(7.61)$ & $(7.77)$ & $(7.33)$ \\
\hline \multicolumn{6}{|l|}{ Village Characteristics } \\
\hline \multirow[t]{2}{*}{ Net income (log) } & & $-95.39^{* *}$ & -41.27 & $250.25^{* * *}$ & \\
\hline & & $(41.26)$ & $(42.37)$ & $(49.25)$ & \\
\hline \multirow[t]{2}{*}{ Net income (log) squared } & & $8.24^{* * *}$ & 4.2 & $-19.42^{* * *}$ & \\
\hline & & $(3.05)$ & $(3.14)$ & $(3.70)$ & \\
\hline \multirow[t]{2}{*}{ Total population (log) } & & $112.41^{* * *}$ & $106.97^{* * *}$ & $70.76^{* * *}$ & \\
\hline & & $(5.19)$ & $(5.11)$ & $(4.23)$ & \\
\hline \multirow[t]{2}{*}{ Distance from village to town } & & 0.27 & 0.17 & 0.44 & \\
\hline & & $(0.37)$ & $(0.37)$ & $(0.37)$ & \\
\hline \multirow[t]{2}{*}{ Villagers working in township (person) } & & 0.23 & 0.19 & 0.9 & \\
\hline & & $(1.12)$ & $(1.10)$ & $(1.07)$ & \\
\hline \multirow[t]{2}{*}{ Illiterates (person) } & & $-0.06^{* *}$ & $-0.06^{*}$ & 0.12 & \\
\hline & & $(0.03)$ & $(0.03)$ & $(0.03)$ & \\
\hline \multirow[t]{2}{*}{ Access to road (dummy) } & & $17.61^{* * *}$ & $18.95^{* * *}$ & 2.27 & \\
\hline & & $(5.34)$ & $(5.37)$ & $(5.03)$ & \\
\hline \multicolumn{6}{|l|}{ Control for: } \\
\hline Types of project & No & No & Yes & Yes & na \\
\hline Province FE & No & No & No & Yes & na \\
\hline R-squared & 0.05 & 0.32 & 0.34 & 0.44 & na \\
\hline $\mathrm{N}$ & 4858 & 4858 & 4858 & 4858 & na \\
\hline
\end{tabular}

Notes. ${ }^{* * *}$ denotes significant at the level 0.01 level; ${ }^{* *}$ denotes significant at the 0.05 level; ${ }^{*}$ denotes significant at the 0.1 level. For column 1-4, robust clustered standard errors at the village level are reported in the parentheses; For column 5 , bootstrap standard error is reported for the DID-PSM estimator. 
province fixed effects. The robust standard errors are clustered at the village level. Column 5 displays the result of the DID-PSM estimation which allows a more flexible functional form than linear equation. The first two rows for the OLS specification suggest that the number of out-migrants are significantly higher in year 2002, compared to 1997, and in villages with Yigong-daizhen projects than without. It can be seen from the third row of Table 6 that the introduction of Yigong-daizhen projects had a positive and significant impact on the number of out-migrants in the village. After controlling for village characteristics, the types of public project in the village and province fixed effects, the introduction of Yigong-daizhen projects on average led to an increase of around 38 local laborers migrating out in the subsequent years as shown in Column 4. The p-value of the coefficients on Yigong-daizhen projects are below 0.01 for all the four specifications. Given that the average number of migrants in villages with Yigong-daizhen projects is around 140 in 1997, these public work projects lead to an increase of out-migration by about 27.1 percent from year 1997 to 2002, 5.4 percent per year on average.

Column 5 shows the result of DID-PSM estimation. The estimator calculates the average treatment effect reweighted by the propensity score, where observations with "extreme" propensity scores (less than 0.1 and larger than 0.9 ) have been dropped. The magnitude of the estimation is lower than the DID specifications with significance at the 0.1 level, indicating the existence of program selection bias that we may not fully capture in the DID settings.

In addition to the main coefficient related to the impact of Yigong-daizhen, the coefficients on village characteristics are of interests as well. For example, after accounting for province fixed effects, the linear term of per capita income in year 1997 is significantly positive, while the squared term of per capita income is significantly negative, which suggests that there exists an inverted U-shape between per capita income and migration probability. Furthermore, and as should be expected, higher population leads to more out-migrants in the village. Better road access also encourages out-migration.

Table 7 exhibits OLS (DID) estimation results by different income quartiles. As DIDPSM estimation requires large sample to construct comparable groups, we do not apply the method here. The coefficients for Yigong-daizhen are positive and significant except for the lowest quartile by income in 1997. In addition, the magnitude of the coefficient for the third quartile is generally the largest among all the four quartiles. These estimates provide some evidence on credit constraints as the households neither too poor nor too rich are the most likely ones to migrate out given the cash income from the public work projects.

In addition to income distribution across villages, the income distribution within villages also affects the migration equilibrium. Yigong-daizhen projects may affect local laborers in different income quartiles within the village differently in terms of their willingness to migrate. However, household level data is needed to take into account the distribution of income within village, which we do not have.

Table 8 presents the results concerning 'increasing productivity' and 'reducing cost' hypotheses. Panel A tests the hypothesis of 'increasing productivity' as a mechanism of Yigong-daizhen projects. We create a dummy variable "productivity improvement" that equals to one for villages with five types of 'productivity improvement' projects: irrigation system improvement, drainage system improvement, soil improvement, small-scale water conservation and terrace construction projects. We exclude projects which may not have effects in the short run, such as school and clinic construction. In addition, we exclude the Grain for Green projects as they mainly benefit the downstream 
Table 7 Impact of Yigong-daizhen project on migrant (by income quartiles)

\begin{tabular}{|c|c|c|c|c|}
\hline & \multicolumn{4}{|c|}{ Dependent variable: number of migrant labor (person) } \\
\hline & DID (1) & DID (2) & DID (3) & DID (4) \\
\hline & \multicolumn{4}{|c|}{ Lowest quartile by net income in $1997(\mathrm{~N}=1214)$} \\
\hline \multirow[t]{3}{*}{ After *Yigong-daizhen } & 1.91 & 0.81 & -4.50 & -4.09 \\
\hline & $(5.45)$ & $(5.63)$ & $(5.97)$ & $(5.87)$ \\
\hline & \multicolumn{4}{|c|}{ Second lowest quartile by net income in $1997(N=1236)$} \\
\hline \multirow[t]{3}{*}{ After *Yigong-daizhen } & $33.63^{* *}$ & $32.83^{* *}$ & 25.87 & $33.85^{* *}$ \\
\hline & $(13.52)$ & $(13.40)$ & $(15.86)$ & $(15.86)$ \\
\hline & \multicolumn{4}{|c|}{ Second highest quartile by net income in $1997(N=1200)$} \\
\hline \multirow[t]{3}{*}{ After *Yigong-daizhen } & $79.70^{* * *}$ & $74.52^{* * *}$ & $38.08^{* *}$ & $57.22^{* * *}$ \\
\hline & $(15.69)$ & $(15.74)$ & $(16.29)$ & $(15.29)$ \\
\hline & \multicolumn{4}{|c|}{ Highest quartile by net income in $1997(\mathrm{~N}=1206)$} \\
\hline \multirow[t]{2}{*}{ After *Yigong-daizhen } & $48.83^{* *}$ & $48.67^{* *}$ & $46.76^{* *}$ & $48.09^{* *}$ \\
\hline & $(23.80)$ & $(22.15)$ & $(21.05)$ & $(21.51)$ \\
\hline \multicolumn{5}{|l|}{ Control for: } \\
\hline Two main effects for Diff-in-Diff & Yes & Yes & Yes & Yes \\
\hline Village level controls & No & Yes & Yes & Yes \\
\hline Types of project & No & No & Yes & Yes \\
\hline Province FE & No & No & No & Yes \\
\hline
\end{tabular}

Notes. ***denotes significant at the level 0.01 level; ${ }^{* *}$ denotes significant at the 0.05 level; ${ }^{*}$ denotes significant at the 0.1 level. Robust clustered standard errors at the village level are reported in the parentheses. The specifications are the same as reported in Table 6.

villages. The dummy equals to zero otherwise. We then interact this dummy with the difference in difference term to measure the difference of Yigong-daizhen's impact in villages with and without 'productivity improvement' projects. All the pairwise interactions and three main effects are included in the regressions but not reported in the table due to space constraints.

Table 8 Impact of Yigong-daizhen project on migrant (hypothesis tests on productivity improvement and cost reduction)

\begin{tabular}{llccc}
\hline & \multicolumn{4}{c}{ Dependent variable: number of migrant labor (person) } \\
\cline { 2 - 5 } & OLS (1) & OLS (2) & OLS (3) & OLS (4) \\
\hline \multirow{2}{*}{ After *Yigong-daizhen *Productivity improvement } & -10.14 & 8.02 & 11.97 & 22.74 \\
& $(33.85)$ & $(28.18)$ & $(27.89)$ & $(25.92)$ \\
& \multicolumn{4}{c}{ Panel A: Productivity improvement } \\
After *Yigong-daizhen *Costs reduction & $62.20^{*}$ & $58.17^{* *}$ & $58.41^{* *}$ & $44.19^{* *}$ \\
& $(32.93)$ & $(28.60)$ & $(28.93)$ & $(27.04)$ \\
Control for: & & & & \\
Two main effects for Diff-in-Diff & Yes & Yes & Yes & Yes \\
Village level controls & No & Yes & Yes & Yes \\
Types of project & No & No & Yes & Yes \\
Province FE & No & No & No & Yes \\
$N$ & 4858 & 4858 & 4858 & 4858 \\
\hline
\end{tabular}

Notes. ${ }^{* *}$ denotes significant at the 0.05 level; ${ }^{*}$ denotes significant at the 0.1 level. Robust clustered standard errors at the village level are reported in the parentheses. 
The findings in Panel A suggest that the impact of Yigong-daizhen on the number of out-migrants is similar in villages with and without 'productivity improvement' projects since the coefficients are not significant. This suggests that productivity improvement is not a key mechanism by which public work projects impact the behavior of potential migrant workers.

Panel B of Table 8 tests the hypothesis of 'reducing cost' as a mechanism of Yigongdaizhen projects. A dummy for "costs reduction" equals to one for villages with road and bridge construction projects during 1998-2002. These villages are more likely to experience migration cost reduction through better connectivity to neighbor cities and villages. The dummy equals to zero in villages without such type of projects. Similar to panel A, the dummy is interacted with the difference in difference term to measure the difference of Yigong-daizhen's impact in villages with and without 'costs reduction' projects. Again, all the pairwise interactions and three main effects are included in the regressions.

The coefficients on the triple difference term are significantly positive and large in magnitude, which indicates that the positive impact of Yigong-daizhen on out-migration is much larger in villages with 'costs reduction' projects than villages without such projects. Thus, the above estimates provide us with some confidence that cost reduction may be a channel for the positive impact of Yigong-daizhen projects on the flow of out-migrants.

Table 9 reports the heterogeneous impacts of Yigong-daizhen projects by program intensity. There are three dimensions capturing differences in program intensity: the number of Yigong-daizhen projects implemented in a village; total labor days participated in such projects; investment in yuan per labor day in such projects. Panel A, B and $\mathrm{C}$ in Table 9 exploit the heterogeneous impacts of Yigong-daizhen projects along these three dimensions.

Table 9 Heterogeneous impact of Yigong-daizhen project on migrant (on number of project, labor and capital intensity)

\begin{tabular}{|c|c|c|c|c|}
\hline & \multicolumn{4}{|c|}{ Dependent variable: number of migrant labor (person } \\
\hline & OLS (1) & OLS (2) & OLS (3) & OLS (4) \\
\hline & \multicolumn{4}{|c|}{ Panel A: One VS. More projects } \\
\hline \multirow[t]{3}{*}{ After *Yigong-daizhen *More than one } & $50.33^{* * *}$ & $50.29^{* * *}$ & $49.14^{* * *}$ & $51.04^{* * *}$ \\
\hline & $(17.62)$ & $(17.44)$ & $(16.86)$ & $(17.16)$ \\
\hline & \multicolumn{4}{|c|}{ Panel B: Labor use: Above average VS. Below average } \\
\hline \multirow[t]{3}{*}{ After *Yigong-daizhen *Labor intensive } & $50.22^{* *}$ & $48.77^{* *}$ & $44.44^{* *}$ & $50.10^{* *}$ \\
\hline & $(21.80)$ & $(21.64)$ & $(21.02)$ & $(21.27)$ \\
\hline & \multicolumn{4}{|c|}{ Panel C: Capital use: Above average VS. Below average } \\
\hline \multirow[t]{2}{*}{ After *Yigong-daizhen ${ }^{*}$ Capital intensive } & 1.78 & 4.21 & 10.73 & 8.72 \\
\hline & $(32.25)$ & $(32.39)$ & $(28.89)$ & (30.68) \\
\hline \multicolumn{5}{|l|}{ Control for: } \\
\hline Two main effects for Diff-in-Diff & Yes & Yes & Yes & Yes \\
\hline Village level controls & No & Yes & Yes & Yes \\
\hline Types of project & No & No & Yes & Yes \\
\hline Province FE & No & No & No & Yes \\
\hline $\mathrm{N}$ & 4858 & 4858 & 4858 & 4858 \\
\hline
\end{tabular}

Notes. ${ }^{* * *}$ denotes significant at the level 0.01 level; ${ }^{* *}$ denotes significant at the 0.05 level; ${ }^{*}$ denotes significant at the 0.1 level. Robust clustered standard errors at the village level are reported in the parentheses. 
Panel A employs a triple difference approach to compare the impact of Yigong-daizhen projects in villages with only one such project to villages with more than one projects. The dummy variable "more than one" equals to one for villages with more than one Yigong-daizhen projects, otherwise zero. The other specifications are the same as in Table 8. The consistently positive and significant coefficients across different specifications indicate that the impact of Yigong-daizhen projects is larger in villages with higher program intensity, i.e., more number of projects.

Panel B employs similar estimation strategy as in Panel A to compare the impact of Yigong-daizhen projects in villages with above average labor use for such projects to villages with below average labor use. The dummy variable "labor intensive" equals to one for villages with above average labor days participation in Yigong-daizhen projects, otherwise zero. The positive and significant coefficients in the four specifications indicate that out-migration flow due to Yigong-daizhen projects is larger in villages with more local labor participated in such projects. This is reasonable since more labor participation is likely to be correlated with more local laborers receiving cash income to finance their migration.

Panel $\mathrm{C}$ examines the heterogeneous impact of Yigong-daizhen projects along the dimension of capital intensity using similar estimation strategies following the above two panels. The dummy variable "capital intensive" equals to one for villages with above average investment per labor day use, otherwise zero. The coefficients in all the four specifications are insignificant, suggesting that that impact of Yigong-daizhen projects is similar in villages with or without capital intensive projects. The result does not work against our main results since higher capital intensity in Yigong-daizhen projects does not necessarily lead to more cash income for local laborers nor reduced migration costs, which are the key channels affecting migration behaviors.

Since the Yigong-daizhen projects in villages ended in different years after year 1997, it will be interesting to learn about how project timing affects its impact on out-migration. We create dummy variables for Yigong-daizhen projects that ended in different years in a village starting from year 1998. If there are projects ended in different years in a village, the ending year of the earliest one is recorded. The dummies are interacted with the "after" variable to measure the impact of Yigong-daizhen projects ended in a specific year on out-migration. The impact of Yigong-daizhen projects ended in 2002 is taken as the baseline group.

Table 10 shows the estimation results. The coefficients reported in the table indicate the difference of Yigong-daizhen's impact between projects that ended in a certain year with projects that ended in the year of the second round of survey (year 2002). 14 out of the 16 coefficients are positive. Moreover, the magnitude of the coefficients is larger for projects that ended earlier. The significance level also increases for older projects. Therefore, the estimation results suggest that out-migration increases over years after the ending of the Yigong-daizhen projects.

\section{Conclusion}

In this paper, we present the impact of public work schemes in China, Yigong-daizhen, on the outmigration of labor at the village level. The results show that the introduction of Yigong-daizhen projects in the villages stimulates the outflow of migrant workers from affected villages. The impact of such projects can be consistently estimated using traditional difference in difference (DID) analysis as well as difference in difference 
Table 10 Impact of Yigong-daizhen project on migrant over time

\begin{tabular}{lllll}
\hline & \multicolumn{3}{c}{ Dependent variable: number of migrant labor (person) } \\
\cline { 2 - 5 } & OLS (1) & OLS (2) & OLS (3) & OLS (4) \\
\hline After *Yigong-daizhen in 1998 & $101.18^{* * *}$ & $69.75^{* *}$ & $54.73^{*}$ & 39.85 \\
& $(37.23)$ & $(32.15)$ & $(31.59)$ & $(30.33)$ \\
After *Yigong-daizhen in 1999 & $74.31^{*}$ & 42.73 & 26.30 & 29.24 \\
& $(44.81)$ & $(38.19)$ & $(37.64)$ & $(35.14)$ \\
After *Yigong-daizhen in 2000 & 38.66 & 42.99 & 35.32 & 38.76 \\
& $(44.05)$ & $(37.70)$ & $(38.91)$ & $(36.00)$ \\
After *Yigong-daizhen in 2001 & 21.57 & 8.44 & -8.02 & -12.11 \\
& $(34.74)$ & $(28.79)$ & $(27.62)$ & $(24.79)$ \\
Control for: & & & & Yes \\
Two main effects for Diff-in-Diff & Yes & Yes & Yes & Yes \\
Village level controls & No & Yes & Yes & Yes \\
Types of project & No & No & Yes & Yes \\
Province FE & No & No & No & 4858 \\
N & 4858 & 4858 & 4858 & \\
\hline
\end{tabular}

Notes. ${ }^{* * *}$ denotes significant at the level 0.01 level; ${ }^{* *}$ denotes significant at the 0.05 level; ${ }^{*}$ denotes significant at the 0.1 level. Robust clustered standard errors at the village level are reported in the parentheses.

propensity score matching (DID-PSM) which accounts for the non-random placement of Yigong-daizhen program. These results are consistent with the predictions of a model of migration behavior in the presence of significant migration cost, and credible market imperfection (Qin 2011). The positive impact of Yigong-daizhen continues to be robust upon controlling for potential heterogeneity of program effect across income quartiles. Specifically, we find evidence suggesting that the impact of Yigong-daizhen on migration is most important for the middle class, which is consistent with the inverted-U shaped relationship between migration and income level in the presence of capital market imperfect (Du et al. 2005; McKenzie and Rapoport 2007). The positive impact of Yigong-daizhen remains upon accounting for heterogeneity in program characteristics, most important in villages with cost reduction projects (such as road construction) and projects with higher intensity (such as more than one projects and more labor intensive projects.) In addition, the impact of Yigong-daizhen on migration accumulates over years.

Our findings also reveal two observations that suggest that the present set of results should be interpreted with caution, and that additional research with better identification techniques and broader data coverage should be encouraged. In particular, in the DID-PSM regression that controls for the program selection on observables, the magnitude and significance of the impact of Yigong-daizhen on out-migration drops to some extent. Given the data limitations, we cannot fully address concerns about selection on unobservable characteristics into the program. The estimation result may be biased upward if some unobservable characteristics are positively correlated with both the placement of Yigong-daizhen program and migration incentives. For example, if economic conditions are improved in the prefecture level city that the village belongs to, the funding for Yigong-daizhen program in the village may increase, and the outmigrants to the city may increase at the same time, due to the economic growth instead of the Yigong-daizhen program. In contrast, if the unobservable characteristics are positively correlated with the placement of Yigong-daizhen program, but negatively 
correlated with migration incentives, the estimation result may be biased downward. For example, if the village head is very capable, he (or she) may be able to lobby more Yigong-daizhen projects to the village. At the same time, if the village head creates more job opportunities within the village, more local laborers may be willing to stay in the village instead of migrating out. In this case, our estimation about Yigong-daizhen's impact on migration is likely to be downward biased. Alternative identification techniques with better correction for program endogeneity and broader data coverage, for example, should be applied in future research.

\section{Endnotes}

${ }^{1}$ Betcherman et al. (2004) summarizes the impact evaluation results of 20 public work programs worldwide. The 20 public work programs cover transition countries, developing countries and developed countries. The results concerning the impact on employment and earnings are both mixed. Among the 18 studies with impact evaluation on employment, seven of them find that public work programs have positive impact on the level of employment. For example, Walsh et al. (2001) investigate the Temporary Employment Program in the period of 1998 to 1999 in Bulgaria and find that there is a 2.5 per cent net impact of improving the chance of the unemployed to have a regular job.

${ }^{2}$ Suggested by Betcherman et al. (2004), of the two studies with impact evaluation on earnings (Rodríguez-Planas and Jacob 2010; Jalan and Ravallion 2003), the evaluation evidence regarding to the impact of public works on earnings is mixed for the transition and developing country programs. For example Rodríguez-Planas and Jacob (2010) find that in Romania, participating in public work programs has a negative impact on employment and the length of unemployment spell in the period of 2000-2001. While according to Jalan and Ravallion (2003), the Trabajar program in Argentina significantly lifts up the net income of the poor participants, where the percentage net gain for the poor 5 per cent is 74\%. Gaiha (1996b) analyzes the impact of EGS on the wages of the poor in Maharashtra, India. Program participation is shown to bring significant positive effect on agricultural wages of the poor possibly since EGS enables them to bargain for higher agricultural wages by improving their fall-back position. Finally, the study also finds that EGS program has an income stabilization effect in agriculturally slack periods.

${ }^{3}$ Gaiha (1996b) examines the targeting precision of the EGS program. It is expected that EGS program is designed to help the poor by providing them job opportunities. However, he finds that the targeting of EGS is no better than the general labor market. In other words, the share of the poor among EGS participants is close to the share of the poor in the labor force. This evidence is further confirmed in Gaiha (2000). In addition, there are more male participants in EGS with a significantly higher wage than the female participants. Another interesting finding with respect to the participation of the EGS is that the poor people turn to depend less on EGS, or to be more likely to withdraw from EGS when the overall economic condition gets better.

${ }^{4}$ Park et al. (2002) studies the targeting effectiveness of the three main poverty reduction programs, namely the Yigong-daizhen program, the subsidized loan program and the budgetary grant program. They find that for both Yigong-daizhen program and the subsidized loan program, the amount of fund allocation to poor counties is not 
significantly correlated with income levels. Only the budgetary grant program is progressive. In addition, they find that being designated as a poor county increases the growth in rural income per capita by 2.28 per cent per year during the period of 19851992 and 0.91 per cent during the period of 1992-1995.

${ }^{5}$ Zhu and Jiang (1995) is the only paper that estimates the impact of Yigong-daizhen program in China with data from three counties. This study finds that Yigong-daizhen projects have improved the income of participating households. However, they simply compare the difference of average income per capita between participating and nonparticipating households without controlling for village characteristics and accounting for program placement endogeneity.

${ }^{6}$ This question has been addressed by Ravallion (1991) for example in the Indian context. Specifically, the initial purpose of the Maharashtra Employment Guarantee Scheme was to discourage worker migration in the slack seasons and drought affected years since some workers would not return in the harvest seasons. Also see Naomi (2008) for evidence on the potential of the National Rural Employment Guarantee Scheme in India on outmigration propensities.

${ }^{7}$ Kanbur (1981) suggests that a rural development program which increases the rural income may indeed increase migration in the villages with imperfect credit market, as the poor now have more money to spend on migration if the gain from migration is greater than the earnings from local employment. Qin (2011) narrows down the concept of rural development programs to public work schemes and provides a theoretical framework to analyze the impact of such programs on interregional movements of labor.

${ }^{8}$ The objective of Grain for Green projects is to increase forest cover and prevent soil erosion on sloped cropland (Uchida et al. 2005).

${ }^{9}$ There are three main differences between Yigong-daizhen projects and other public projects in rural China. First and foremost, the funding of Yigong-daizhen projects comes from the central government, while the funding of the other public projects comes from either the upper government or the villages themselves. Second, the laborers hired by Yigong-daizhen projects are the local villagers, unlike the other public projects which generally outsourcing to companies outside the village. Third, as one of the pro-poor policy, Yigong-daizhen projects are likely to be placed in villages with more poor population and less infrastructure (National Development and Reform Commission NDRC 2005).

${ }^{10}$ As mentioned in Section 3, in the questionnaire, there is a question asking "How many villagers worked outside, and lived outside in 1997 and 2002." We use this information in village $i$, time $t$ as the measure of Outmig $g_{i, t}$.

${ }^{11}$ In the questionnaire, whether Yigong-daizhen program had been implemented in the village can be detected from the question "the source of funding of the public investment projects". If the source of funding of any of the public investment project in village $i$ was from Yigongdaizhen program, then the variable $\mathrm{YGDZ}_{\mathrm{i}}$ will be coded as " 1 " for village $i$, " 0 " otherwise.

${ }^{12}$ In China, each township consists of several administrative villages, while each administrative village consists of several natural villages governed by village committee. The distance from the village committee seat to township government seat measures how isolated a natural village is, which is likely to affect the placement of public projects.

${ }^{13}$ The 19 types of public projects are: roads and bridges construction, school construction, clinic construction, drinking water facility provision, irrigation system 
improvement, drainage system improvement, electricity infrastructure construction, telephone installation, cable TV or loudspeaker installation, soil improvement project, small scale water conservation, terrace construction, environment improvement project, forest closure project, public forest planting, Grain for Green project, meadow construction, recreational center construction and others.

${ }^{14}$ The 46 covariates include all the village characteristics that can be found in the questionnaire in the year of 1997, including the number of migrants, the proportion of households engaged in agricultural production, the proportion of non-minority households, total population, total acres of land, plain, terrace, irrigated area, sown area, grain production, grassland, forest, garden, commercial forest and pond; the number of laborers, local laborers, commuting laborers, illiterates, residents with high school or higher education, schools, clinics, village clinics; the number of households with access to electricity, tap water, telephone; access to paved road (dummy), nearest distance from paved road to the village committee, the type of road in the village (categorical), the type of vehicle used when travelling to town (categorical), time used when travelling to town, the proportion of flat area in the village, hilly area in the village, the level of erosion (categorical), the quality of grassland (categorical), the type of water resources (categorical), the distance from village to main water resources, the number of local villagers working in the township government and working in the county government, any outstanding debt in the village (dummy), the amount of outstanding debt in the village, the number of enterprises in the village, the number of village operated enterprises.

\section{Competing interests}

The IZA Journal of Labor \& Development is committed to the IZA Guiding Principles of Research Integrity. The authors declare that they have observed these principles.

\section{Acknowledgements}

We are very grateful to Xiaobo Zhang and Yongmiao Hong for their extremely helpful comments. We also would like to thank an anonymous referee for very useful comments. All remaining errors are ours.

Responsible editor: Jackline Wahba

Received: 7 November 2013 Accepted: 25 February 2014

Published: 24 Mar 2014

\section{References}

Acharya S (1990) The Maharashtra Employment Guarantee Scheme: A Study of Labor Market Intervention. Asian Regional Team for Employment Promotion (ARTEP). International Labor Organization

Angelucci M (2013) Migration and Financial Constraints: Evidence from Mexico. Accepted for publication at Rev Econ Stat

Basu AK, Chau N, Kanbur R (2009) A theory of employment guarantees: contestability, credibility and distributional concerns. J Public Econ 93(3-4):482-497

Bazzi S (2013) Wealth Heterogeneity, Income Shocks, and International Migration: Theory and Evidence from Indonesia. Working Paper, Boston University, Boston

Betcherman G, Dar A, Olivas K (2004) Impacts of Active Labor Market Programs: new Evidence from Evaluations with Particular Attention to Developing and Transition Countries. Social Protection Discussion Paper 0402. World Bank, Washington, DC

Chan KW (2008) Internal Labor Migration in China: Trends, Geographical Distribution and Policies. In: Proceedings of the United Nations Expert Group Meeting on Population Distribution, Urbanization, Internal Migration and Development, ESA/P/WP.206, United Nations, pp 93-122

Du Y, Park A, Wang S (2005) Migration and rural poverty in China. J Comp Econ 33(4):688-709

Gaiha R (1996a) How dependent are the rural poor on the employment guarantee scheme in India? J Dev Stud 32 (5):669-694

Gaiha R (1996b) Wages, participation and targeting - the case of the employment guarantee scheme in India. J Int Dev $8(6): 785-803$

Gaiha R (2000) On the targeting of the employment guarantee scheme in the Indian State of Maharashtra. Econ Plann 33(3):203-219

Galor O, Zeira J (1993) Income distribution and macroeconomics. Rev Econ Stud 60(1):35-52

Ha W, Yi J, Zhang J (2009) Internal Migration and Income Inequality in China: Evidence from Village Panel Data. Human Development Research Paper 2009/27. United Nations Development Program

Heckman JJ, Ichimura H, Todd P (1998) Matching as an econometric evaluation estimator. Rev Econ Stud 65(2):261-294 
Jalan J, Ravallion M (2003) Estimating the benefit incidence of an antipoverty program by propensity score matching. J Bus Econ Stat 21(1):19-30

Kanbur R (1981) Short-run Growth Effects in a Model of Costly Migration with Borrowing Constraints: Will Rural Development Work. In: Currie D et al (eds) Essays on Microeconomics and Economic Development. Croom Helm, London

Lee MH (2011) Migration and children's welfare in China: the schooling and health of children left behind. J Dev Areas 44(2):165-182

Luo R, Zhang L, Huang J, Rozelle S (2007) Elections, fiscal reform and public goods provision in rural China. J Comp Econ 35(3):583-611

Matsuyama K (2008) Aggregate Implications of Credit Market Imperfections. In: Acemoglu D, Rogoff K, Woodford M (eds) NBER Macroeconomics Annual 2007, 22nd edn. University of Chicago Press, Chicago

McKenzie D, Rapoport H (2007) Network effects and the dynamics of migration and inequality: theory and evidence from Mexico. J Dev Econ 84(1):1-24

Meng X, Manning C, Li S, Effendi TN (2010) The Great Migration: Rural-Urban Migration in China and Indonesia. Edward Elgar Publishing, Northampton

Naomi MJ (2008) The Impact of NREGA on Rural-Urban Migration: Field Survey of Villupuram District. CCS Working Paper No.202. Summer Research Internship Programme. Centre for Civil Society, Tamil Nadu

National Development and Reform Commission (NDRC) (2005) Regulation of Yigong-Daizhen Projects., 2005. http://www.ndrc.gov.cn/zcfb/zcfbl/zcfbl2005/t20051230_55351.htm. Accessed 30 Dec 2005

Park A, Wang S, Wu G (2002) Regional poverty targeting in China. J Pub Econ 86(1):123-153

Qin Y (2011) Evaluating the Impact of Public Work Schemes on Interregional Movements of Labor: Theoretical Framework and Empirical Evidence from China. Cornell University, Master thesis

Ravallion M (1991) Market Responses to Anti-Hunger Policies: Effects on Wages, Prices and Employment. In: Drèze J, Sen A (eds) The Political Economy of Hunger, vol 2, Famine Prevention 1(7). Oxford University Press, USA, pp 241-279

Ravallion M, Datt G, Chaudhuri S (1993) Does Maharashtra's employment guarantee scheme guarantee employment? Effects of the 1988 wage increase. Econ Dev Cult Change 41(2):251-275

Rodríquez-Planas N, Jacob B (2010) Evaluating active labor market programs in Romania. Empir Econ 38(1):65-84

Rozelle S, Park A (1998) Targeted poverty investments and economic growth in China. World Dev 26(12):2137-2151

Sjaastad LA (1962) The costs and returns of human migration. J Polit Econ 70(5):80-93

Taylor JE, Rozelle S, De Brauw A (2003) Migration and incomes in source communities: a new economics of migration perspective from China. Econ Dev Cult Change 52(1):75-101

Uchida E, Xu J, Rozelle S (2005) Grain for green: cost-effectiveness and sustainability of China's conservation set-aside program. Land Econ 8(2):247-264

Walsh K, Kotzeva M, Dolle E, Dorenbos R (2001) Evaluation of the net Impact of Active Labour Market Programs in Bulgaria. Ministry of Labour and Social. Policy, Bulgaria

Zhang KH, Song S (2003) Rural urban migration and urbanization in China: evidence from time-series and cross-section analyses. China Econ Rev 14(4):386-400

Zhao Y (1999a) Labor migration and earnings differences: the case of rural China. Econ Dev Cult Change 47(4):767-782

Zhao Y (1999b) Leaving the countryside: rural-to-urban migration decisions in China. Am Econ Rev 89(2):281-286

Zhu N (2002) The impacts of income gaps on migration decisions in China. China Econ Rev 13(2-3):213-230

Zhu L, Jiang Z (1995) "Yigong-Daizhen" in China: A new Experience with Labor-Intensive Public Works in Poor Areas. In: von Braun J (ed) Employment for Poverty Reduction and Food Security. International Food Policy Research Institute, Washington DC, pp 75-107

10.1186/2193-9020-3-4

Cite this article as: Chau et al: Do public work schemes deter or encourage outmigration? Empirical evidence from China. IZA Journal of Labor \& Development 2014, 3:4

\section{Submit your manuscript to a SpringerOpen ${ }^{\circ}$ journal and benefit from:}

- Convenient online submission

- Rigorous peer review

- Immediate publication on acceptance

- Open access: articles freely available online

- High visibility within the field

Retaining the copyright to your article

Submit your next manuscript at $\gg$ springeropen.com 